\title{
Transcutaneous multichannel electrogastrography: normal parameters in a Brazilian population
}

\author{
Nayara Salgado CARVALHO',2, Diego Cardoso BAIMA ${ }^{1}$, Ricardo Correa BARBUTI', \\ Paulo Jose Pereira Campos CARVALHO ${ }^{2}$, Joffre REZENDE FILHO ${ }^{3}$ and Tomas NAVARRO-RODRIGUEZ ${ }^{1}$
}

\begin{abstract}
Background - Electrogastrography (EGG) is a noninvasive technique for the assessment of gastric myoelectrical activity using electrodes placed on the abdominal surface. Changes in gastric myoelectrical activity may be associated with diseases such as gastroparesis, functional dyspepsia, nausea, and recurrent vomiting. In Brazil, no studies to date have assessed gastric myoelectrical activity using multichannel EGG in healthy individuals. Objective - To establish normal values of transcutaneous multichannel EGG in healthy Brazilian individuals. Methods - This was a prospective study including 20 healthy individuals who underwent EGG. Recording was performed during two periods: a preprandial recording was performed for 30 minutes, and a postprandial recording was performed for 30 minutes after a soft-solid meal of $400 \mathrm{kcal}$ (20 grams of proteins, 60 grams of carbohydrates, and 9 grams of fat). Results - We assessed dominant frequency (DF) parameters, \%DF distribution, the instability coefficient, and the power ratio (PR). A total of 20 individuals ( 11 women and 9 men) with a mean age of $39.5 \pm 7.4$ years were included. Mean DF $(95 \% \mathrm{CI})$ ranged from 2.4 to $3.1 \mathrm{cpm}$ in the resting phase and 2.6 to $3.2 \mathrm{cpm}$ in the postprandial period. The $\% \mathrm{DF}$ in normogastria range was $>70 \%$ in all healthy individuals. We identified that only one individual did not present a positive response to the test meal, and the other 19 individuals showed a PR greater than 1 . The instability coefficient did not change significantly with meal intake. Conclusion - Multichannel EGG may be applied in future studies to evaluate gastric motility disorders in the Brazilian population.
\end{abstract}

HEADINGS - Gastrointestinal motility. Electrophysiology. Gastric emptying. Electrodiagnosis.

\section{INTRODUCTION}

Electrogastrography (EGG) is a noninvasive technique used to assess the myoelectrical activity of the stomach through electrodes placed on the abdominal surface ${ }^{(1)}$. In 1922, Alvarez described the first EGG recordings( ${ }^{(2)}$, but it was only in the 1950s when Davis et al. began the first studies to systematize the technique ${ }^{(3)}$. Since 1990, with the introduction of computerized signal analysis, EGG has been popularized ${ }^{(4)}$. The gastric myoelectrical activity consists of slow waves (electrical control activity) and electrical potentials termed spikes (electrical response activity) ${ }^{(5,6)}$. Over time, studies have evaluated the simultaneous recordings of skin electrodes and serosal or mucosal electrodes, demonstrating that EGG captures the gastric myoelectrical activity ${ }^{(7-10)}$. A recent study reviewed the validity of EGG, including the relationship between EGG and the internal serosal recording of slow waves of the stomach and between EGG and gastric contractions ${ }^{(11)}$. Lin et al. (2000) correlated serosal recording with EGG in the evaluation of the postprandial response of gastric myoelectrical activity ${ }^{(12)}$.

Recording of gastric myoelectrical activity with skin electrodes is subject to numerous movement artifacts and electrical interferences from other organs. The applicability and reproducibility of the method have depended on technological developments over time, the manner in which the examinations were recorded, appropriate equipment settings, development of new amplifiers and filters, and the use of multichannel equipment with bipolar electrodes that offer better signal quality ${ }^{(13-15)}$.

Gastrointestinal motility disorders, functional gastrointestinal tract diseases, or inducing stimuli can alter the myoelectrical activity of the stomach, leading to EGG abnormalities ${ }^{(16)}$. The normal slow wave frequency in humans is three cycles per minute (cpm). Abnormalities in gastric myoelectrical activity include dysrhythmias that can be classified as bradygastria, tachygastria, and arrhythmia ${ }^{(4,9,17)}$. Studies that evaluated the recording of gastric myoelectrical activity with serosal electrodes defined the following, according to frequency range: normogastria, two to four cpm; bradygastria, 0.5 to two $\mathrm{cpm}$; and tachygastria, four to nine $\mathrm{cpm}^{(4,18,19)}$. However, the variation in the frequency of gastric myoelectrical activity considered normal has been reported with widely different values ${ }^{(20)}$, such as two to four $\mathrm{cpm}^{(17,21,22)}$; two to $4.5 \mathrm{cpm}^{(23)} ; 2.4$ to $3.6 \mathrm{cpm}^{(24-26)}$; and 2.4 to $3.7 \mathrm{cpm}^{(27)}$. This frequency variation can alter the percentages of normogastria, bradygastria, and tachygastria in the EGG analysis; therefore, these values are important.

A review of Brazilian demographic data published by the Brazilian Institute of Geography and Statistics (Instituto Brasileiro de Geografia e Estatística - IBGE) in 2010 indicated that the ethnic and racial composition of the Brazilian population is the result of a confluence of people of various origins, with 33\% of Amerindian origin, $28 \%$ of African origin, and $39 \%$ of European origin ${ }^{(28)}$. This finding raised the question of whether the parameters of normal-

Declared conflict of interest of all authors: none

Disclosure of funding: no funding received

${ }^{1}$ Hospital das Clínicas da Faculdade de Medicina da Universidade de São Paulo (HCFMUSP), Divisão de Gastroenterologia e Hepatologia Clínica, São Paulo, SP, Brasil. ${ }^{2}$ Hospital Israelita Albert Einstein, Departamento de Endoscopia, Núcleo de Fisiologia Gastrointestinal - NUFIG, São Paulo, SP, Brasil. 3.Universidade Federal de Goiás, Hospital das Clínicas da UFG, Serviço de Gastroenterologia e Hepatologia Goiânia, GO, Brasil.

Corresponding author: Nayara Salgado Carvalho. E-mail: nayara-salgado@hotmail.com 
ity in the literature should be used in Brazil. In addition, studies conducted in Brazil were performed with single-channel EGG devices $^{(29-31)}$. No multichannel EGG studies have been conducted in the Brazilian population; therefore, the aim of this study was to evaluate the gastric myoelectrical activity and to define parameters of normality for multichannel EGG in a Brazilian population.

\section{METHODS}

\section{Subjects}

The study protocol was approved by the Ethics Committee of Hospital das Clínicas de São Paulo, University of São Paulo (register number 16442). All participants signed a free and informed consent form. The EGG examination was performed at the Gastroenterology Diagnostics Center, Hospital das Clínicas, São Paulo.

Healthy volunteers without dyspeptic symptoms were invited to participate in the study. Participants were aged between 18 and 70 years and had a body mass index $(\mathrm{BMI})<30 \mathrm{~kg} / \mathrm{m}^{2}$. The exclusion criteria were any previously diagnosed condition, previous gastrointestinal tract surgery, psychiatric illness, any medication that could affect gastrointestinal function (e.g. prokinetics, antihypertensives, beta-blockers, antidepressants), pregnancy, lactation, and alcohol consumption.

Data from 20 healthy volunteers ( 11 women and 9 men) with a mean age of $41 \pm 10$ years were included in the final analysis.

\section{Multichannel EGG}

Multichannel EGG was performed with the Polygraf Solar EGG module electrogastrography system developed by Medical Measurement Systems - MMS (Laborie Europe, Enschede, The Netherlands), which is composed of six bipolar electrodes, one reference electrode, one ground electrode, and a strap for recording respiratory movement.

\section{- Skin preparation}

At the abdominal site where the electrodes were positioned, the skin was completely cleaned, and abrading with sandpaper was performed to ensure that the impedance between the electrode pairs remained low.

\section{- Electrode placement}

The MMS Ag/AgCl electrodes (N-00-S, MMS) were positioned in the abdominal region on top of the skin. The ground electrode was placed in an area with little movement and distant from the stomach (near the right shoulder), and the respiratory strap was placed in the lower thoracic region. The other six electrodes were arranged on the mesogastrium as follows: electrode three, used as the main electrode, was placed two $\mathrm{cm}$ above the midpoint between the xiphoid process and the navel; another two electrodes were placed $45^{\circ}$ to the upper left side of the main electrode (electrodes one and two). Another electrode was placed four $\mathrm{cm}$ to the right and on the same line as main electrode three (electrode four). Two more electrodes were placed two $\mathrm{cm}$ below main electrode three on the left and right sides (electrodes five and six, respectively) ${ }^{(15,32)}$.

\section{- Subject position}

The examination was performed with the volunteers in a comfortable supine position so that there was no or minimal body movement. EGG records were performed at the same time of day.
The subject was instructed not to speak, move, read, or make phone calls during the procedure to ensure that the position was the same throughout the recording. Whenever inevitable body movement or artifacts occurred, the time was written down, and these segments were removed from the analysis. The volunteers were also instructed not to fall asleep during the recording ${ }^{(33)}$.

\section{- Recording duration}

EGG was performed without recording for 10 to 15 minutes until the tracing was stabilized, and recordings were performed in two periods: the first 30-minute period was performed with the patient under fasting conditions for eight hours, and the second 30 -minute period was performed after ingestion of the test meal ${ }^{(34)}$. The test meal consisted of 20 grams of protein, 60 grams of carbohydrates, and 9 grams of fat, totaling $400 \mathrm{kcal}^{(35)}$.

\section{- EGG signal analysis}

The recorded EGG signal was subjected to visual and computerized analysis. Visual analysis was performed to eliminate movement artifacts. Fast fourier transform (FFT) and running spectral analysis were applied in the computerized analysis. The raw EGG sinal recording and FFT power plot and running spectral analysis of the EGG signal are shown in FIGURE $1^{(36)}$. Each running spectrum was four minutes and 16 seconds long. The frequencies of each spectrum were interpreted by FFT and were classified as follows: bradygastria (1-2 cpm), normogastria (2-4 cpm), tachygastria $(4-10 \mathrm{cpm})$, and duodenal/respiratory rhythm $(10-15 \mathrm{cpm})^{(35)}$.

The following parameters, derived from the computerized EGG signal analysis, were determined ${ }^{(4,8,15,35,37-39)}$ :

(i) mean dominant frequency (DF) at baseline and in the postprandial period and the dominant power (DP). The mean DF is the frequency with the highest mean potential in the spectrum. The frequency that occurs at the highest gastric potential is determined by the absolute peak value, and the mean frequency and power are calculated by averaging the individual spectra;

(ii) percentage of the DF in normogastria (2-4 cpm), bradygastria (1-2 cpm), tachygastria (4-10 cpm), and duodenal/respiratory origin $(10-15 \mathrm{cpm})$. This evaluation was performed using the running spectral analysis method and by calculating the percentage distribution in these frequency ranges (normogastria, bradygastria, tachygastria, and duodenal/respiratory origin) for the baseline and postprandial periods (FIGURE 2);

(iii) the power ratio (PR) or relative power variation is the ratio of the postprandial to baseline DP values (FIGURE 3);

(iv) the instability coefficient (IC) was introduced to define the characteristic variation in the DF within the normal range. It is calculated as the standard deviation divided by the mean frequency. A lower IC value will result in a more stable DF.

\section{- Definition of normal EGG}

Normal EGG was considered to be present when the percentage of the DF in normogastria was $>70 \%$ during both periods $\mathrm{s}^{(17,40-42)}$ and the increase in postprandial power was $>1^{(4,35)}$.

\section{Statistical analysis}

A descriptive analysis was first conducted using the mean, standard deviation (SD), median, 25th (P25) and 75th (P75) percentiles, and minimum and maximum values. The KolmogorovSmirnov test was used to evaluate the probability distribution of the quantitative traits. 

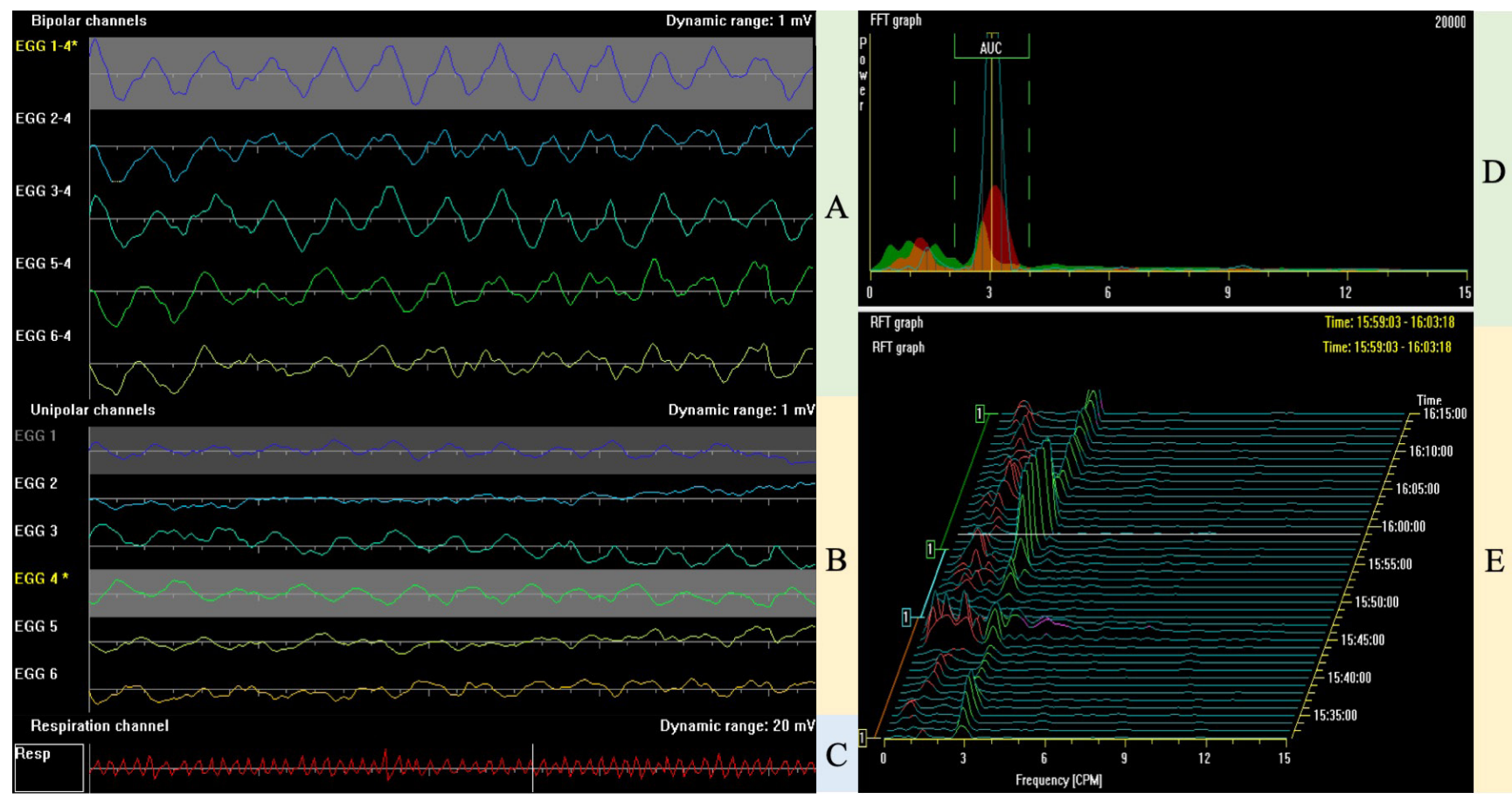

FIGURE 1. Multichannel electrogastrography signal analysis. A. EGG waves tracing recorded in bipolar channels; B. EGG waves tracing recorded in monopolar channels; C. Respiratory movements trace channel; D. Fast Fourier transform (FFT) of EGG power spectrum; E. multiple FFT lines - running spectral analysis.
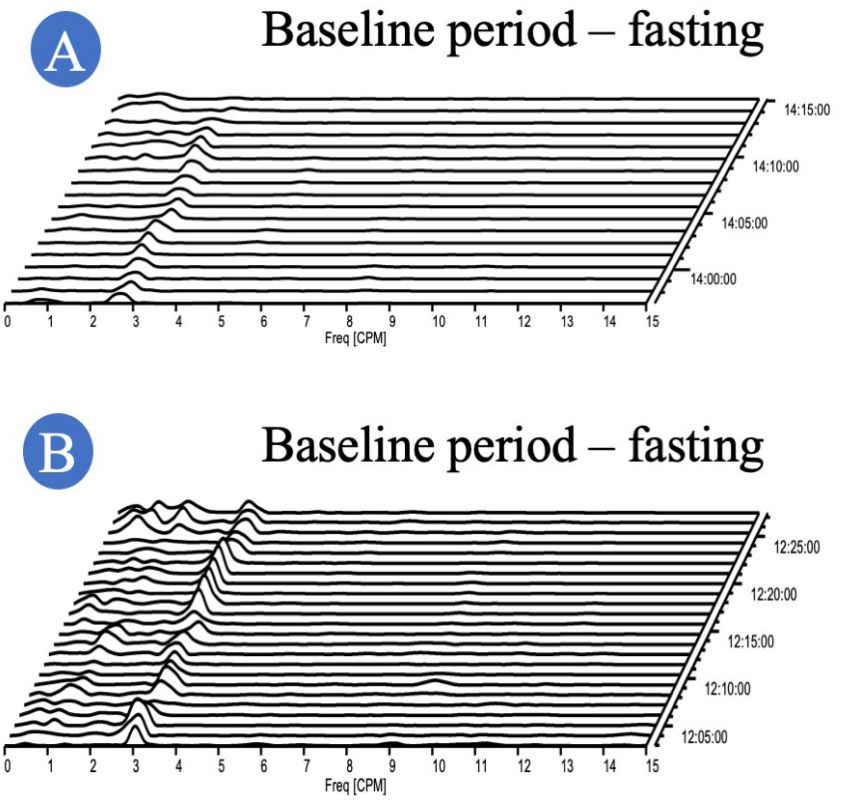

Postprandial period

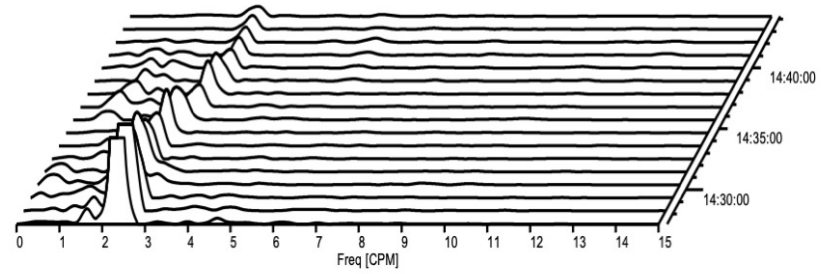

Postprandial period

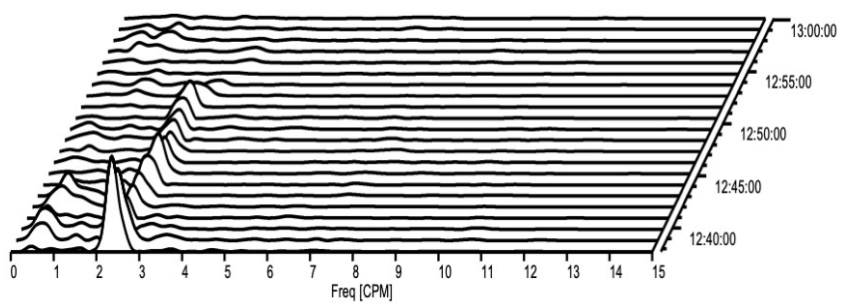

FIGURE 2. Example of traces showing the FFT lines in normal EGG recordings in the baseline and postprandial periods (A and B). The dominant frequency is maintained in the frequency range between two and four cpm. 


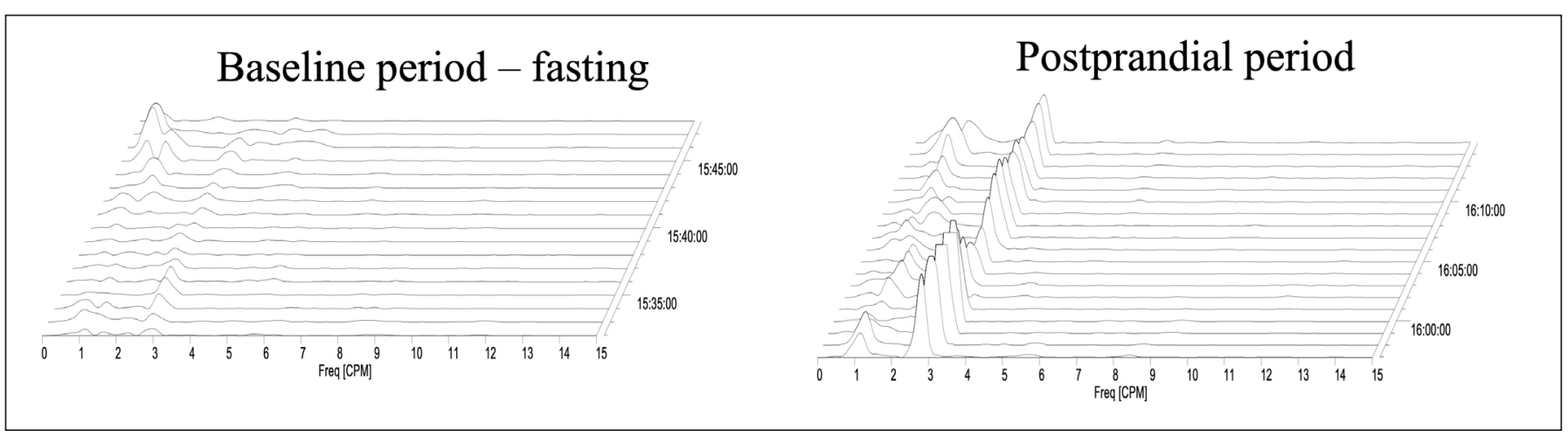

FIGURE 3. Example showing normal traces (running spectral analysis) with a positive response to the test meal (increased power - wave amplitude - in the postprandial period).

The hypothesis that the baseline DF and postprandial DF exhibited the same distribution during both periods was tested using a paired $t$-test. All tests performed used a two-tailed $\alpha$ of 0.05 and a confidence interval (CI) of $95 \%$ and were performed with using Statistical Package for the Social Sciences version 25 (IBM Corp. Released 2017. IBM SPSS Statistics for Windows, Version 25.0. Armonk, NY: IBM Corp.)

\section{RESULTS}

A total of 20 healthy individuals were evaluated, including $11(55 \%$; $95 \% \mathrm{CI}=33.8-74.9 \%)$ females and $9(45 \%$; $95 \% \mathrm{CI}=$ 25.1-66.2) males. The mean age of the study subjects was $41 \pm 10$ years (TABLE 1).

TABLE 1. Descriptive statistics including the demographic data and the outcomes achieved at multichannel electrogastrography.

\begin{tabular}{lccc}
\hline & Mean \pm SD & $\begin{array}{c}\text { Median } \\
(\text { P25-P75) }\end{array}$ & $\begin{array}{c}\text { Minimum- } \\
\text { maximum }\end{array}$ \\
\hline $\begin{array}{l}\text { Age } \\
\text { Fasting dominant } \\
\text { frequency }\end{array}$ & $21.0 \pm 10.0$ & $40.0(34.0-48.0)$ & $27-68$ \\
$\begin{array}{l}\text { Postprandial } \\
\text { dominant frequency }\end{array}$ & $2.9 \pm 0.2$ & $2.7(2.6-2.9)$ & $2.4-3.1$ \\
$\begin{array}{l}\text { Power ratio } \\
\begin{array}{l}\text { Overall dominant } \\
\text { frequency }\end{array}\end{array}$ & $9.5 \pm 15.4$ & $3.7(1.9-9.0)$ & $0.36-67.0$ \\
$\begin{array}{l}\text { Normogastria } \\
\text { fasting (\%) }\end{array}$ & $87.5 \pm 11.8$ & $87.3(77.0-100)$ & $70.5-100$ \\
$\begin{array}{l}\text { Normogastria } \\
\text { postprandial (\%) }\end{array}$ & $90.4 \pm 9.7$ & $91.5(84.6-100)$ & $72.2-100$ \\
$\begin{array}{l}\text { Dominant frequency } \\
\text { instability coefficient } \\
\text { fasting }\end{array}$ & $14.5 \pm 5.4$ & $15.6(11.7-17.1)$ & $2.7-27.2$ \\
$\begin{array}{l}\text { Dominant frequency } \\
\text { instability coefficient } \\
\text { postprandial (\%) }\end{array}$ & $11.2 \pm 3.5$ & $11.6(8.4-13.5)$ & $5.7-19.7$ \\
\hline
\end{tabular}

The mean DF at rest was $2.7 \pm 0.2 \mathrm{cpm}$, and the mean postprandial DF was $2.9 \pm 0.2 \mathrm{cpm}$. The difference of $0.2 \mathrm{cpm}$ was statistically significant $(P$-value $=0.010)$.

The DF showed little variability $(2.9 \pm 0.3 \mathrm{cpm})$. Also, the mean and median percentages of the DF in normogastria in the baseline and postprandial periods were $87.5 \pm 11.8$ and $90.4 \pm 9.7 \%$ and $87.3 \%$ $(77.0-100.0 \%)$ and $91.5 \%(84.6-100.0 \%)$, respectively. There was no significant difference between the two periods $(P$-value $=0.116)$.

The PR exhibited heterogeneity among the subjects, with a mean of $9.5 \pm 15.4$ and a median of $3.7(1.9-9.0)$.

\section{DISCUSSION}

With technological advancements over time, the method by which EGG is recorded and its new settings have made the test more reliable $^{(13-15)}$. For example, the difficulties capturing low amplitude signals and the susceptibility to artifacts have decreased due to technological advances in the technique and as new professionals learn the method ${ }^{(43)}$.

Our study is the first to apply multichannel EGG in the Brazilian population using equipment with new settings, amplifiers, and filters and bipolar electrodes. This greater variety of channels facilitates choosing the best signal among all recordings to represent the optimal measurement of gastric myoelectrical activity ${ }^{(15,44)}$. One study showed that data obtained with multichannel EGG may provide increased information on gastric myoelectrical activity in patients with suspected motility disorders and in patients with unexplained nausea, vomiting, gastroparesis, and other dyspeptic symptoms ${ }^{(15,45)}$. EGG also helps to identify the pathophysiology of diseases associated with gastric slow waves or dysrhythmia ${ }^{(46,47)}$. Abnormalities found on EGG have been compared to finding of slow gastric emptying on scintigraphy. Some studies concluded that abnormalities in both tests are present in subsets of patients, but the two tests may define different populations, becoming complementary examinations ${ }^{(48-50)}$.

The variation in the overall DF in our population was 2.3-3.3 $\mathrm{cpm}$, and this range of values is similar to that reported in the literature ${ }^{(24,25,51,52)}$. The mean DF was also assessed in both periods, and the variation was between 2.6 and $2.9 \mathrm{cpm}$ at baseline and 2.8 and $3.0 \mathrm{cpm}$ postprandial. All individuals in our cohort were healthy volunteers not having any evidence of fasting hyperglycemia or autonomic neuropathy that might interfere with the results observed in this population ${ }^{(53,54)}$. Rezende Filho et al. (2005) evaluated EGG abnormalities in patients with Chagas disease in Brazil and compared them with a control group of healthy individuals and found mean baseline and postprandial DF variations of $1.17-3.05 \mathrm{cpm}$ and $1.88-2.38 \mathrm{cpm}$, respectively. However, that study was performed with a single-channel EGG device ${ }^{(31)}$, which is different from our device, which had multiple channels, and may have been a factor in the difference in the results. 
Additionally, we observed an increase in the mean DF between the baseline $(2.7 \mathrm{cpm})$ and postprandial $(2.9 \mathrm{cpm})$ periods, and this difference was statistically significant. One study showed that this increase may occur when solid foods are included in the test meal rather than liquid foods only ${ }^{(40)}$.

In the EGG analysis, we observed a high mean percentage of the DF in normogastria ( $87.5 \%$ at baseline and $90.4 \%$ postprandial), remaining above $70 \%$ in both periods, which is in agreement with the literature ${ }^{(4,35,39)}$.

Another important finding was the PR, as we identified that only one individual did not present a positive response to the test meal, and the other 19 individuals showed a PR greater than 1 . A $\mathrm{PR}<1$ may indicate an unsatisfactory stomach motor response to the given stimulus (test meal), and a PR $>1$ indicates a satisfactory response of the stomach, according to several studies and reviews on the topic ${ }^{(17,19,35,40,55)}$.

There is no international consensus on the DF instability coefficient (DFIC). A smaller IC value is known to result in a more stable $\mathrm{DF}^{(4,15)}$. In our study, the DFIC at baseline ranged from $2.7 \%$ to $27.2 \%$, and it ranged from $5.7 \%$ to $14.5 \%$ in the postprandial period, with no significant change after meal ingestion. The literature reports that the DFIC may increase during pregnancy, in patients with gastroesophageal reflux disease ${ }^{(14,56)}$, and in patients with clinical improvement after use of prokinetics, which may be due to the increased variability of changes in gastric motility activated by prokinetics ${ }^{(57)}$. The power in fasting may possibly vary according to interdigestive electromotor complex, as the recording is only 30 minutes. This may explain variations in the IC and PR.
In conclusion, the use of multichannel EGG in healthy individuals of the Brazilian population, where there is significant miscegenation, yielded data consistent with the literature, thus allowing the application of EGG in future studies evaluating gastric motility disorders in this population.

\section{Research involving human participants}

The study protocol was approved by the Ethics Committee of Hospital das Clínicas de São Paulo, University of São Paulo (register number 16442).

\section{Informed consent}

All participants signed a free and informed consent form.

\section{Authors' contribution}

All authors idealized the project, collected patients' data, worked on supervision, realization and validation based on repeatability of the exams, contributed to the safety analysis, conducted the writing and critical review of the study. All authors have contributed to the writing of the manuscript.

\section{Orcid}

Nayara Salgado Carvalho: 0000-0001-9167-8957.

Diego Cardoso Baima: 0000-0002-6430-5431.

Ricardo Correa Barbuti: 0000-0002-1910-119X.

Paulo Jose Pereira Campos Carvalho: 0000-0002-9041-8835.

Joffre Rezende Filho: 0000-0002-5599-1070.

Tomas Navarro-Rodriguez: 0000-0002-3458-699X.

Carvalho NS, Baima DC, Barbuti RC, Carvalho PJPC, Rezende Filho J, Navarro-Rodriguez T. Eletrogastrografia multicanal transcutânea: parâmetros normais em uma população brasileira. Arq Gastroenterol. 2020;57(4):428-33.

RESUMO - Contexto - Eletrogastrografia (EGG) é técnica não invasiva que avalia a atividade miolétrica gástrica utilizando eletrodos localizados na superfície abdominal. Alterações na atividade miolétrica gástrica podem estar associadas a distúrbios como gastroparesia, dispepsia funcional, náuseas e vômitos recorrentes. No Brasil, não há estudos até o momento que tenham avaliado a atividade miolétrica gástrica pela EGG multicanal transcutânea em indivíduos saudáveis. Objetivo - Estabelecer valores de normalidade da EGG multicanal transcutânea em indivíduos brasileiros saudáveis. Métodos - Este foi um estudo prospectivo, incluindo 20 indivíduos saudáveis submetidos a EGG. O registro foi realizado em dois períodos: um período pré-prandial foi registrado por 30 minutos, e um período pós-prandial por 30 minutos após a ingesta de uma dieta de prova com consistência sólida e pastosa de $400 \mathrm{kcal}$ (20 gramas de proteínas, 60 gramas de carboidratos e 9 gramas de gordura). Resultados - Foram avaliados os parâmetros de frequência dominante (FD), distribuição da \% de FD, coeficiente de instabilidade e "power ratio" (PR). Foram incluídos 20 indivíduos (11 mulheres e 9 homens) com idade média de 39,5 +/- 7,4 anos. A FD média (95\%CI) variou de 2,4 a 3,1 cpm no período de basal (pré-prandial) e de 2,6 a 3,2 cpm no período pós-prandial. A \% da FD na faixa de normogastria foi $>70 \%$ em todos os indivíduos saudáveis. Identificamos que apenas um indivíduo não apresentou resposta positiva a refeição de prova, e os outros 19 indivíduos apresentaram PR $>1$. O coeficiente de instabilidade não mudou significativamente com a ingesta da refeição de prova. Conclusão - A EGG multicanal transcutânea pode ser aplicada em estudos futuros para a avaliar distúrbios da motilidade gástrica na população brasileira.

DESCRITORES - Motilidade gastrointestinal. Eletrofisiologia. Esvaziamento gástrico. Eletrodiagnóstico.

\section{REFERENCES}

1. Leahy A, Besherdas K, Dayman C, Mason I, Epstein O. Abnormalities of the electrogastrogram in functional gastrointestinal disorders. Am J Gastroenterol 1999;94:1023-8

2. Alvarez WC, Mahoney LJ. Action currents in stomach and intestine. Am J Physiol 1922:58:476-93.

3. Davis RC, Garafolo L, Gault FP. An exploration of abdominal potentials. J Comp Physiol Psychol. 1957;50:519-23.

4. Chen JD, Mc Callum RW. Eletrogastrography: principles and applications. Chen JD, McCallum RW E, editor. New York: Raven; 1994;45-73.
5. Sarna SK. Gastrointestinal Electrical Activity: Terminology. Gastroenterology. 1975;68:1631-5.

6. Kelly KA. Motility of the stomach and gastroduodenal tract. New York: Raven; 1981;393-410.

7. Brown BH, Smallwood RH, Duthie HL, Stoddard CJ. Intestinal smooth muscle electrical potentials recorded from surface electrodes. Med Biol Eng. 1975;97-102.

8. Smout AJPM, Van Der Schee EJ, Grashuis JL. What is measured in electrogastrography? Dig Dis Sci. 1980;33-9.

9. Abell TL, Malagelada JR. Glucagon-evoked gastric dysrhythmias in humans shown by an improved electrogastrographic technique. Gastroenterology. 1985;1392-80. 
10. Hamilton JW, Bellahsene BE, Reichelderfer M, Webster JG, Bass P. Human electrogastrograms - Comparison of surface and mucosal recordings. Dig Dis Sci. 1986;33-9.

11. Yin J, Chen JDZ. Electrogastrography: Methodology, validation and applications. J Neurogastroenterol Motil. 2013;19:5-17.

12. Lin Z, Chen JDZ, Schirmer BD, McCallum RW. Postprandial response of gastric slow waves: Correlation of serosal recordings with the electrogastrogram. Dig Dis Sci. 2000;45:645-51.

13. Mintchev MP, Kingma YJ, Bowes KL. Accuracy of cutaneous recordings of gastric electrical activity. Gastroenterology. 1993;1273-80.

14. Krusiec-Świdergoł B, Jonderko K. Multichannel electrogastrography under a magnifying glass - An in-depth study on reproducibility of fed state electrogastrograms. Neurogastroenterol Motil. 2008;625-34.

15. Lin X, Chen JZ. Abnormal gastric slow waves in patients with functional dyspepsia assessed by multichannel electrogastrography. Am J Physiol Gastrointest Liver Physiol. 2001;1370-5.

16. Sha W, Pasricha PJ, Chen JDZ. Correlations Among Electrogastrogram, Gastric Dysmotility, and Duodenal Dysmotility in Patients With Functional Dyspepsia. J Clin Gastroenterol. 2009;43:716-22.

17. Camilleri M, Hasler WL, Parkman HP, Quigley EMM, Soffer E. Measurement of gastrointestinal motility in the GI laboratory. Gastroenterology. 1998;115:747-62.

18. Qian LW, Pasricha PJ, Chen JDZ. Origins and patterns of spontaneous and drug-induced canine gastric myoelectrical dysrhythmia. Dig Dis Sci. 2003;48: 508-15.

19. Chen JD, Schirmer BD, McCallum RW. Serosal and cutaneous recording of gastric myoelectrical activity in patients with gastroparesis. Am J Physiol. 1994;266:90-8

20. Chang FY. Electrogastrography: Basic knowledge, recording, processing and its clinical applications. J Gastroenterol Hepatol. 2005;20:502-16.

21. Chen JD, Zou X, Lin X, Ouyang S, Liang J. Detection of gastric slow wave propagation from the cutaneous electrogastrogram. Am J Physiol. 1999; 277: 424-30.

22. Chen JD, Co E, Liang J, Pan J, Sutphen J, Torres-Pinedo RB, Orr WC. Patterns of gastric myoelectrical activity in human subjects of different ages. Am J Physiol Liver Physiol. 1997;272:1022-7.

23. Koch KL, Hong SP, Xu L. Reproducibility of gastric myoelectrical activity and the water load test in patients with dysmotility-like dyspepsia symptoms and in control subjects. J Clin Gastroenterol. 2000;31:125-9.

24. Parkman HP, Hasler WL, Barnett JL, Eaker EY. Electrogastrography: A document prepared by the gastric section of the American Motility Society Clinical GI Motility Testing Task Force. Neurogastroenterol Motil. 2003;15:89-102.

25. Koch KL, Bingaman S, Tan L, Stern RM. Visceral perceptions and gastric myoelectrical activity in healthy women and in patients with bulimia nervosa. Neurogastroenterol Motil. 1998;10:3-10.

26. Koch KL, Stern RM, Vasey M, Botti JJ, Creasy GW, Dwyer A. Gastric dysrhythmias and nausea of pregnancy. Dig Dis Sci. 1990;35:961-8.

27. Chang CS, Lien HC, Yeh HZ, Poon SK, Tung CF, Chen GH. Effect of cisapride on gastric dysrhythmia and emptying of indigestible solids in type-II diabetic patients. Scand J Gastroenterol. 1998;33:600-4.

28. Censo Demográfico 2010. Características da população: resultados do universo. Rio de Janeiro: IBGE, 2011.

29. Oba-Kuniyoshi AS, Oliveira JA, Moraes ER, Troncon LEA. Postprandial symptoms in dysmotility-like functional dyspepsia are not related to disturbances of gastric myoelectrical activity. Brazilian J Med Biol Res. 2004;37:47-53.

30. Rezende Filho J. Estudo da atividade mioelétrica gástrica por eletrogastrografia cutânea: eletrogastrograma / Myoeletric gastric activity through cutaneous electrogastrography: electrogastrogram. Arq Gastroenterol. 1994;32:54-65.

31. Rezende Filho J, De Rezende JM, Melo JRDC. Electrogastrography in patients with Chagas' disease. Dig Dis Sci. 2005;50:1882-8.

32. Patterson M, Rintala TR, Lloyd TD, Abernethy L, Houghton TD, Williams J. Validation of electrodeplacement in neonatal electrogastrography. Dig Dis Sci. 2001;46:2245-9.
33. Orr WC, Crowell MD, Lin B, Harnish MJ, Chen JD. Sleep and gastric function in irritable bowel syndrome: derailing the brain-gut axis. Gut. 1997:41:390-3.

34. Levanon D, Zhang M, Chen JD. Efficiency and efficacy of the electrogastrogram. Dig Dis Sci. 1998;43:1023-30

35. Yin J, Chen JDZ. Electrogastrography: Methodology, Validation and Applications. J Neurogastroenterol Motil. 2013;19:5-17.

36. Chen J. A computerized data analysis system for electrogastrogram. Comput Biol Med. 22:45-57.

37. Riezzo G, Russo F, Indrio F. Electrogastrography in adults and children: the strength, pitfalls, and clinical significance of the cutaneous recording of the gastric electrical activity. Biomed Res Int. 2013;282757.

38. Mintchev MP, Bowes KL. Extracting quantitative information from digital electrogastrograms. Med Biol Eng Comput. 1996;34:244-8.

39. Chen JD, McCallum RW. Clinical applications of electrogastrography. Am J Gastroenterol. 1993;88:1324-36.

40. Chen J, McCallum RW. Gastric slow wave abnormalities in patients with gastroparesis. Am J Gastroenterol. 1992;87:477-82.

41. Pfaffenbach B, Adamek RJ, Kuhn K, Wegener M. Electrogastrography in healthy subjects. Dig Dis Sci. 1995;40:1445-50.

42. Lin Z, Eaker EY, Sarosiek I, McCallum RW. Gastric myoelectrical activity and gastric emptying in patients with functional dyspepsia. Am J Gastroenterol. 1999;94:2384-9

43. O'Grady G, Abell TL. Gastric arrhythmias in gastroparesis: low- and highresolution mapping of gastric electrical activity. Gastroenterol Clin North Am. 2015:44:169-84

44. Chen J, McCallum RW. Effect of milk on myoelectrical activity of the stomachan electrogastrographic study. Med Biol Eng Comput. 1992;30:564-7.

45. Geldof H, Van Der Schee EJ, Van Blankenstein M, Grashuis JL. Electrogastrographic study of gastric myoelectrical activity in patients with unexplained nausea and vomiting. Gut. 1986;250:165-71.

46. Simonian HP, Panganamamula K, Chen JZ, Fisher RS, Parkman HP. Multichannel electrogastrography (EGG) in symptomatic patients: a single center study. Am J Gastroenterol. 2004;99:478-485.

47. Bortolotti M, Sarti P, Barbara L, Brunelli F. Gastric Myoelectric Activity in Patients with Chronic Idiopathic Gastroparesis. Neurogastroenterol Motil. 1990;2:104-8.

48. Chen JD, Lin Z, Pan J, McCallum RW. Abnormal gastric myoelectrical activity and delayed gastric emptying in patients with symptoms suggestive of gastroparesis. Dig Dis Sci. 1996;41:1538-45.

49. Parkman HP, Miller MA, Trate D, Knight LC, Urbain JL, Maurer AH, Fisher RS. Electrogastrography and gastric emptying scintigraphy are complementary for assessment of dyspepsia. J Clin Gastroenterol. 1997;24:214-9.

50. You CH, Lee KY, Chey WY, Menguy R. Electrogastrographic study of patients with unexplained nausea, bloating, and vomiting. Gastroenterology. 1980;79:311-4.

51. Couturier D, Rozé C, Paolaggi J, Debray C. Electrical activity of the normal human stomach. Am J Dig Dis. 1972;17:969-76.

52. Geldof H, van der Schee EJ, Grashuis JL. Electrogastrographic characteristics of interdigestive migrating complex in humans. Am J Physiol. 1986;250:G165-71.

53. Hasler W.L, Soudah H.C, Dulai G., Owyang C. Mediation of Hyperglycemia-Evoked Gastric Slow-Wave Dysrhythmias by Endogenous Prostaglandins. Gastroenterology. 1995;108:727-36.

54. Jebbink HJA, Bruijs PPM, Bravenboer B, Akkermans LMA, Smout AJPM. Gastric myoletrical activity in patients with type I diabetes mellitus and autonomic neuropathy. Dig Dis Sci. 1994;39:2376-83.

55. Parkman HP, Harris AD, Miller MA, Fisher RS. Influence of age, gender, and menstrual cycle on the normal electrogastrogram. Am J Gastroenterol. 1996;91:127-33.

56. Riezzo G, Pezzolla F, Darconza G, Giorgio I. Gastric Myoelectrical Activity in the First Trimester of Pregnancy: A Cutaneous Electrogastrographic Study. Am J Gastroenterol. 1992;87:702-7.

57. Lim HC, Lee SI, Chen JDZ, Park H. Electrogastrography associated with symptomatic changes after prokinetic drug treatment for functional dyspepsia. World J Gastroenterol. 2012;18:5948-56. 